\title{
Rancang Bangun Sistem Informasi Manajemen Keuangan RT/RW Berbasis Web
}

\author{
Erwin Widianto $^{1}$, Dede Kurniadi ${ }^{2}$ \\ Jurnal Algoritma \\ Sekolah Tinggi Teknologi Garut \\ J1. Mayor Syamsu No. 1 Jayaraga Garut 44151 Indonesia \\ Email : jurnal@itg.ac.id \\ 1606012@itg.ac.id \\ 22dede.kurniadi@itg.ac.id
}

\begin{abstract}
Abstrak - Rukun Tetangga/Rukun Warga (RT/RW) adalah suatu lembaga masyarakat sekitar yang dibentuk dengan melalui musyawarah di daerah setempat yang bertujuan untuk mensejahterakan masyarakat setempat dalam rangka pemerintahaan. Untuk menunjang terbentuknya masyarakat yang sejahtera perlu adanya pengelolaan yang baik terutama dalam pelayanan masyarakat salah satu contohnya dalam pegelolaan keuangan RT/RW setempat seperti iuran warga serta adanya report pengeluaran dan pemasukan keuangan. Akan tetapi peramasalahan yang dihadapi belum adanya manajemen yang mengatur keuangan iuran warga seperti pencatatan keuangan yang masuk maupun pengeluaran yang harus dicatat masih secara manual serta masyarakat tidak bisa melihat apa saja iuran yang sudah dibayar dan yang belum dibayar. Tujuan dalam penelitian ini adalah merancang dan membangun sistem informasi manajemen keuangan RT/RW berbasi web. Metodologi yang digunakan untuk merancang dan membangun sistem informasi tersebut adalah metodologi Unififed Approach (UA) dari Ali Bahrami dengan tahapan yang dilakukan diantaranya Object Oriented Analisys (OOA), Object Oriented Design (OOD) dan Object Oriented Programing (OOP). Hasil dari penelitian ini menghasilkan sistem informasi manajemen keuangan RT/RW berbasis web yang dapat digunakan oleh pengelola keuangan dalam mengelola keuangan warga, selain itu warga juga dapat melihat data atau laporan keuangannya masing - masing.
\end{abstract}

Kata Kunci - Berbasis Web; Iuran Warga; Keuangan; Manajemen; Sistem Informasi.

\section{PENDAHULUAN}

Dengan adanya sebuah perkembangan teknologi dan perkembangan suatu sistem informasi tentunya dapat mebantu kegiatan akan menjadi lebih mudah untuk dilakukan dan untuk menghemat waktu dalam suatu pekerjaan sehingga menjadi suatu kebutuhan pokok bagi manusia [1]. Sistem informasi yaitu suatu yang memiliki hubungan satu dengan lainnya yang ada pada organisasi untuk mengatasi pengolahan data harian dan sebagai pendukung untuk menghasilkan sebuah informasi. Sekarang ini hampir semua orang tidak bisa terlepas dari internet, baik itu berbelanja, membeli makanan, yang dilakukan secara online dengan syarat yaitu menggunakan smartphone atau komputer yang bisa digunakan dan bisa terhubung dengan jaringan internet [2]. Tidak hanya untuk melakukan sebuah transaksi jual beli, manajemen keuangan RT/RW juga dapat dilakukan degan secara online sehingga kita tidak perlu datang langsung ke kordinator dengan adanya teknologi ini. Rukun Tetangga/Rukun Warga (RT/RW) adalah suatu lembaga masyarakat sekitar yang dibentuk dengan melalui musyawarah di daerah setempat yang bertujuan untuk mensejahterakan masyarakat setempat dalam rangka pemerintahaan [3]. Selain itu RT/RW mempunyai suatu peranan yang sangat penting bagi masyarakat setempat terutama dalam nilai - nilai budaya dan kehidupan masyarakat salah satu contohnya terutama dalam kesatuan masyarakat setempat untuk membangun masyarakat yang sejahtera. Maka dari itu $\mathrm{RT} / \mathrm{RW}$ diharuskan dapat memberikan suatu pelayanan maupun informsi yang baik dan akurat bagi masyarakat 
agar masyarakat dapat rukun dan makmur serta sejahtera. Untuk menunjang terbentuknya masyarakat yang sejahtera perlu adanya pengelolaan yang baik terutama dalam pelayanan masyarakat salah satu contohnya dalam pegelolaan keuangan RT/RW setempat seperti iuran warga serta adanya report pengeluaran dan pemasukan keuangan. Hal tersebut merupakan salah satu solusi untuk meningkatkannya kesejahteraan khususnya di lingkungan RT/RW. Akan tetapi ada beberapa permasalahan bagi RT/RW salah satunya belum adanya manajemen yang mengatur keuangan iuran warga seperti pencatatan keuangan yang masuk maupun pengeluaran yang harus dicatat masih secara manual, pada peraturan daerah tersebut adanya program iuran warga pada program RT/RW di daerah tersebut, namun terdapat kendala ketika masyarakat tidak bisa melihat apa saja iuran yang sudah dibayar dan yang belum dibayar. Oleh karena itu, maka diperlukannya sebuah sistem informasi manajemen keuangan RT/RW untuk mempermudah pengelola keuangan dalam memanajemen iuran warga dan mempermudah warga dalam melihat data atau laporan keuangannya masing - masing.

Sebelumnya terdapat lima penelitian, dimana penelitian pertama [4] yang berjudul "Perancangan Sistem Informasi Pengelolaan Administrasi Keuangan Sekolah Menengah Atas Mengunakan Metode Pendekatan Unified Approach". Penelitian kedua [5] yang berjudul "Sistem Informasi Pengelolaan Keuangan Dana Bantuan Pada Kecamatan Arjosari". Penelitian ketiga [6] yang berjudul "Perancangan Sistem Informasi Pengolahan Administrasi Keuangan Sekolah Menengah Pertama Islam Terpadu Assalam Garut". Penelitian keempat [7] yang berjudul "Implementasi Sistem Informasi Keuangan Siswa Berbasis SMS Gateway di SMK Muhammadiyah 2 Kadungora". Penelitian kelima [8] yang berjudul "Pemodelan Sistem Informasi Pendataan Warga Dan Biaya Operasional Lingkungan Pada Komplek Perumahan Harmoni Park Berbasis Zachman Framework". Dari penelitian - penelitian tersebut, sama - sama membangun suatu sistem informasi yaitu sistem informasi manajemen keuangan, namun pada penelitian kali ini saya akan melakukan penelitian tentang sistem infomasi manajemen keuangan dalam mengelola keuangan baik itu laporan keuangan yang masuk dan yang keluar selain itu juga dapat mengelola laporan iuran warga. Berdasarkan dari latar belakang, maka dalam penelitian ini penulis menyusun artikel dengan judul "Rancang Bangun Sistem Informasi Manajemen Keuangan RT/RW Berbasis Web".

\section{METODOLOGI PENELITIAN}

Metodologi yang digunakan untuk merancang dan membangun sistem informasi manajemen keuangan $\mathrm{Rt} / \mathrm{Rw}$ adalah menggunakan Unified Approach (UA) dan menggunakan Unified Modelling Language (UML) sebagai dasar pemodelannya [9]. Penggunaan metodologi UA tersebut berdasarkan penelitian yang menggunakan metodologi UA dalam rancang bangun sistem informasi [10]. Dimana tahapan yang dilakukan berdasarkan metodologi UA diantaranya tahapan Object Oriented Analysis (OOA), tahapan Object Oriented Design (OOD) dan tahapan Object Oriented Programming (OOP). Berikut ini merupakan metodologi UA yang disajikan pada Work Breakdown Structure (WBS), sebagaimana disajikan pada Gambar 1.

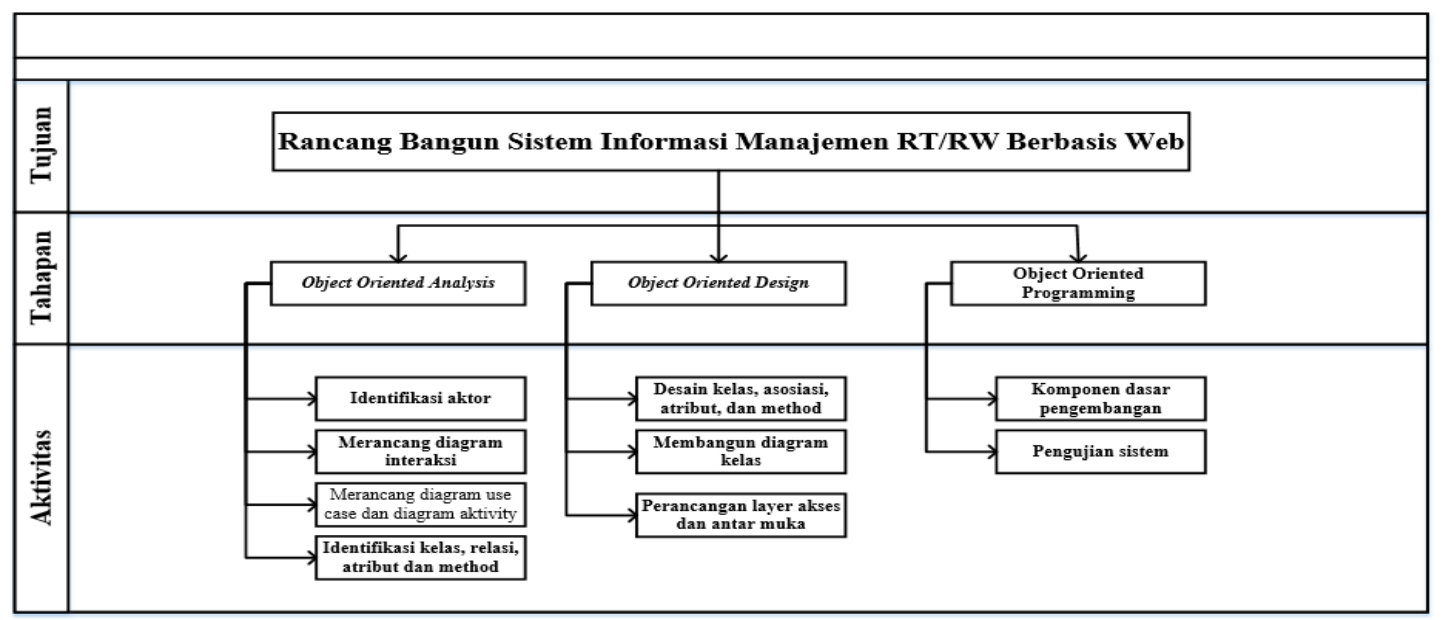

Gambar 1: Work Breakdown Structure 
1. Object Oriented Analysis (OOA), dimana pada tahap ini didefinisikan sebagai tahapan untuk mengidentifiksi rekayasa perangkat lunak (aplikasi) serta sebagai persyaratan dalam merancang dan mengembangkan perangkat lunak berorientasi objek [11]. Adapun aktivitas yang dilakukan diantaranya mengidentifikasi aktor, merancang diagram interaksi, merancang diagram use case dan diagram activity dan mengidentifikasi kelas, relasi, atribut dan method.

2. Object Oriented Design (OOD), dimana pada tahap ini didefinisikan sebagai tahapan untuk memahami konsep perancangan yang mengimplementasikan dari hasil anaisis sebelumnya, dimana pada tahap ini memberikan pemahaman bagi pemrogram dalam merancang perangkat lunak [12]. Adapun aktivitas yang dilakukan diantaranya mendesain kelas, asosiasi, atribut dan method, membangun diagram kelas dan merancang layer akses dan antarmuka.

3. Object Oriented Programming (OOP), dimana pada tahap ini didefinisikan sebagai tahapan untuk mengimplementasikan program atau perancangan pembuatan kode program dengan melihat pada tahapan sebelumnya, yaitu tahapan OOA dan tahapan OOD [10]. Adapun aktivitas yang dilakukan diantaranya implementasi komponen dasar pengembangan dan pengujian sistem.

\section{HASIL DAN PEMBAHASAN}

\section{A. Object Oriented Analysis}

Aktivitas pertama yang dilakukan pada tahapan ini adalah mengidentifikasi aktor. Berdasarkan hasil wawancara, aktor yang terlibat dalam proses bisnis aplikasi sistem informasi manajemen keuangan RT/RW diantaranya warga dan bendahara. Dimana warga bertindak sebagai PBA (Primary Bussines Actor) dan bendahara bertindak sebagai PSA (Primary System Actor). Dari beberapa jenis kegiatan atau aktor tersebut disajikan pada Tabel 1 .

Tabel 1: Identifikasi Aktor

\begin{tabular}{|c|c|c|c|}
\hline Aktor & Tipe Aktor & Jenis Kegiatan & Keterangan \\
\hline Warga & PBA & $\begin{array}{l}\text { Melihat laporan data tunggakan } \\
\text { iuran }\end{array}$ & $\begin{array}{l}\text { Sebagai orang yang terlibat } \\
\text { dalam melakukan aktivitas } \\
\text { untuk melihat status } \\
\text { pembayaran iuran }\end{array}$ \\
\hline Bendahara & PSA & $\begin{array}{l}\text { Menerima dan mencatat iuran } \\
\text { yang masuk memberikan catatan } \\
\text { iuran untuk di publikasikan }\end{array}$ & $\begin{array}{l}\text { Sebagai orang yang } \\
\text { menerima iuran warga dan } \\
\text { mencatat iuran yang masuk } \\
\text { dan Sebagai orang yang } \\
\text { memberikan hasil catatan } \\
\text { iuran warga }\end{array}$ \\
\hline
\end{tabular}

Kemudian setelah aktor teridentifikasi, selanjutnya membuat use case diagram. Berikut ini merupakan use case diagram keseluruhan pada sistem informasi manajemen keuangan RT/RW yang disajikan dalam bentuk gambar, sebagaimana tampak pada Gambar 2. 


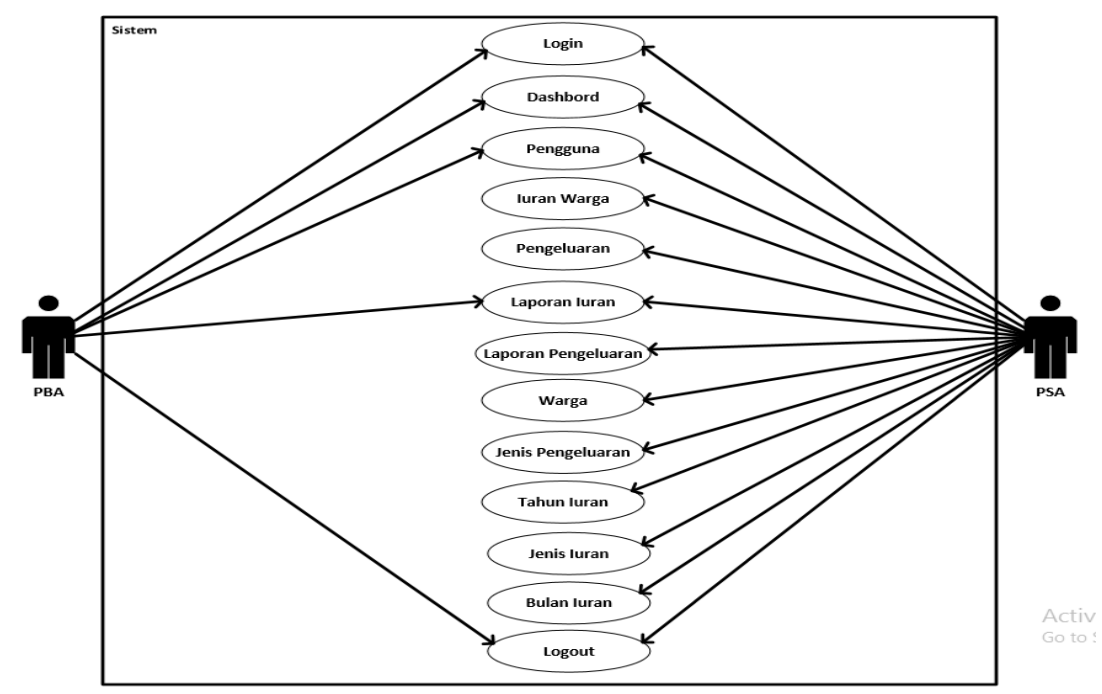

Gambar 2: Use Case Diagram Keseluruhan Sistem Informasi Manajemen Keuangan RT/RW

\section{B. Object Oriented Design}

Pada tahapan ini aktivitas pertama yang dilakukan adalah merancang kelas, relasi, atribut, asosiasi dan method. Kemudian setelah itu merancang class diagram, dimana pada kedua perancangan tersebut di dasari dari tahapan sebelumnya yaitu tahapan object oriented analysis. Berikut ini merupakan perancangan class diagram sistem informasi manajemen keuangan RT/RW yang disajikan pada Gambar 3.

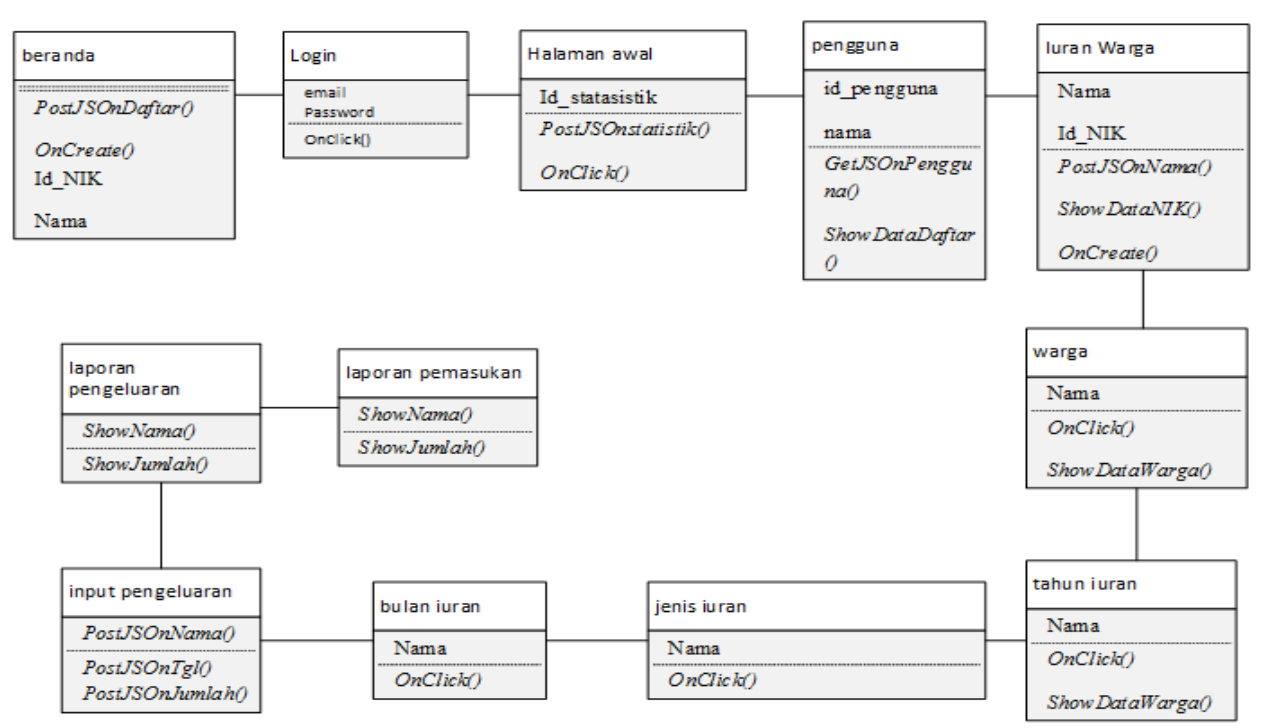

Gambar 3: Class Diagram Sistem Informasi Manajemen Keuangan RT/RW

Kemudian setelah itu, selanjutnya merancang layer akses dan antarmuka. Dimana pada perancangan layer akses dan antarmuka tersebut bertujuan untuk menggambarkan cerminan dari kegiatan sistem mulai dari database hingga dengan tampilan interface. Berikut ini merupakan layer akses dan antarmuka pada sistem informasi manajemen keuangan RT/RW yang disajikan pada Gambar 4. 


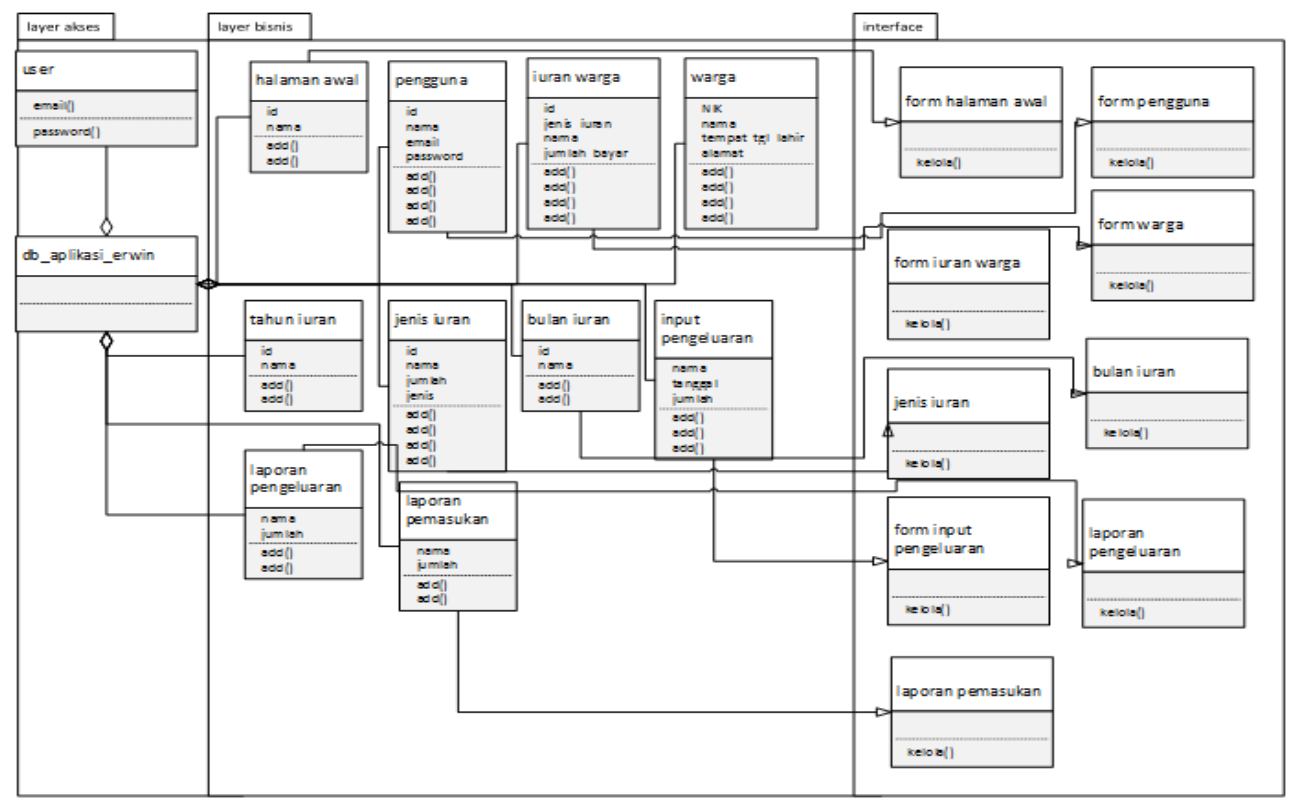

Gambar 4: Perancangan Layer Akses dan Layer Antarmuka Sistem Informasi Manajemen Keuangan RT/RW

\section{Object Oriented Programming}

Pada tahapan ini merupakan implementasi dari perancangan user interface sistem informasi manajemen keuangan RT/RW. Dimana perancangan user interface dari sistem informasi manajemen keuangan RT/RW yang sudah dibuat sebagaimana seperti berikut ini :

1. Implementasi User Interface Halaman Login

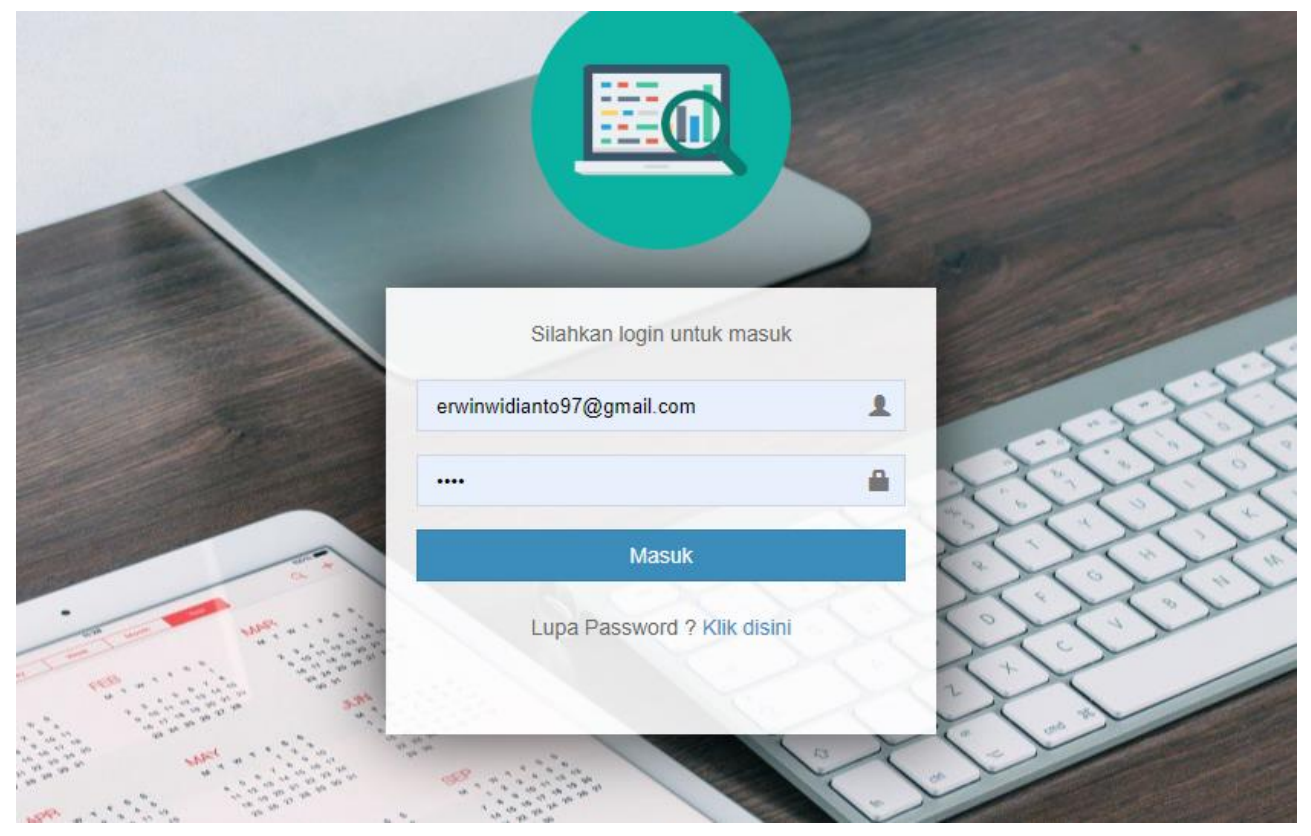

Gambar 5: Halaman Login Warga dan Bendahara 
2. Implementasi User Interface Halaman Utama Bendahara

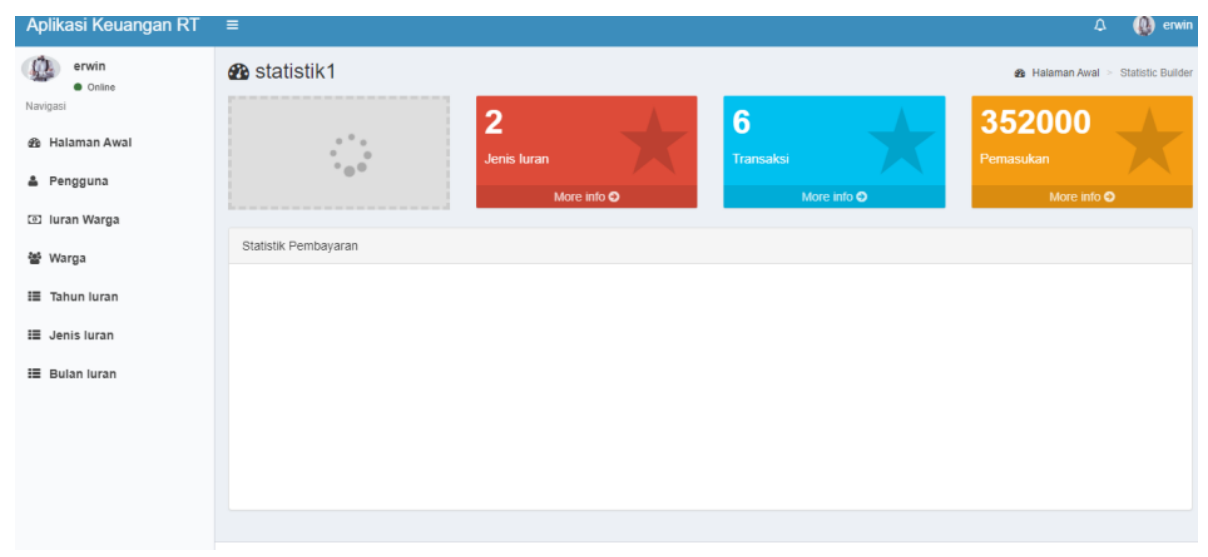

Gambar 6: Halaman Utama Bendahara

3. Implementasi User Interface Halaman Utama Warga

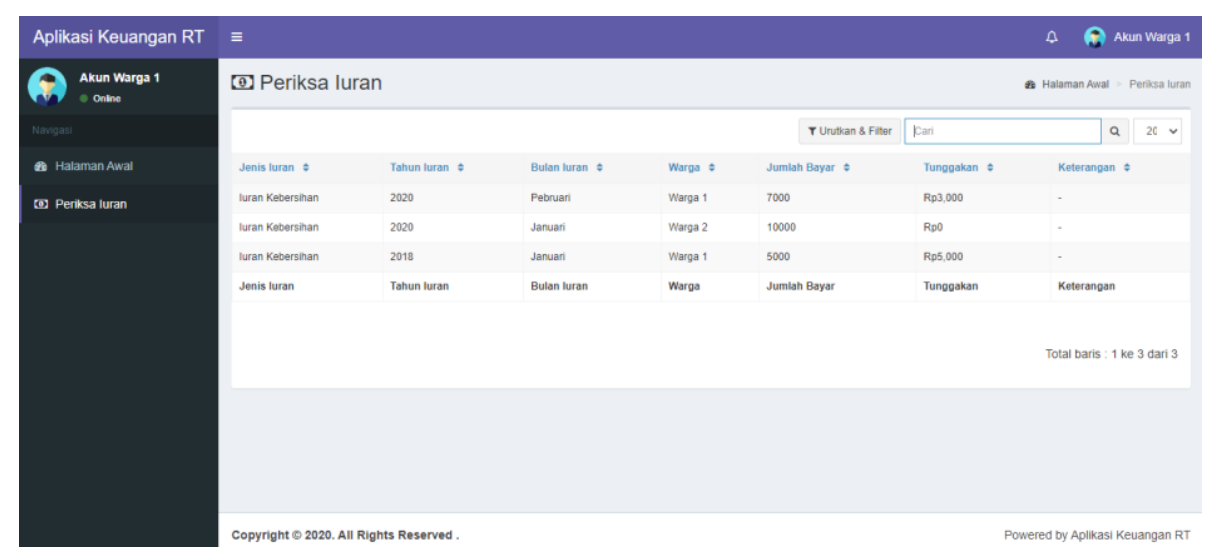

Gambar 7: Halaman Utama Warga

4. Implementasi User Interfce Halaman Laporan Pemasukan

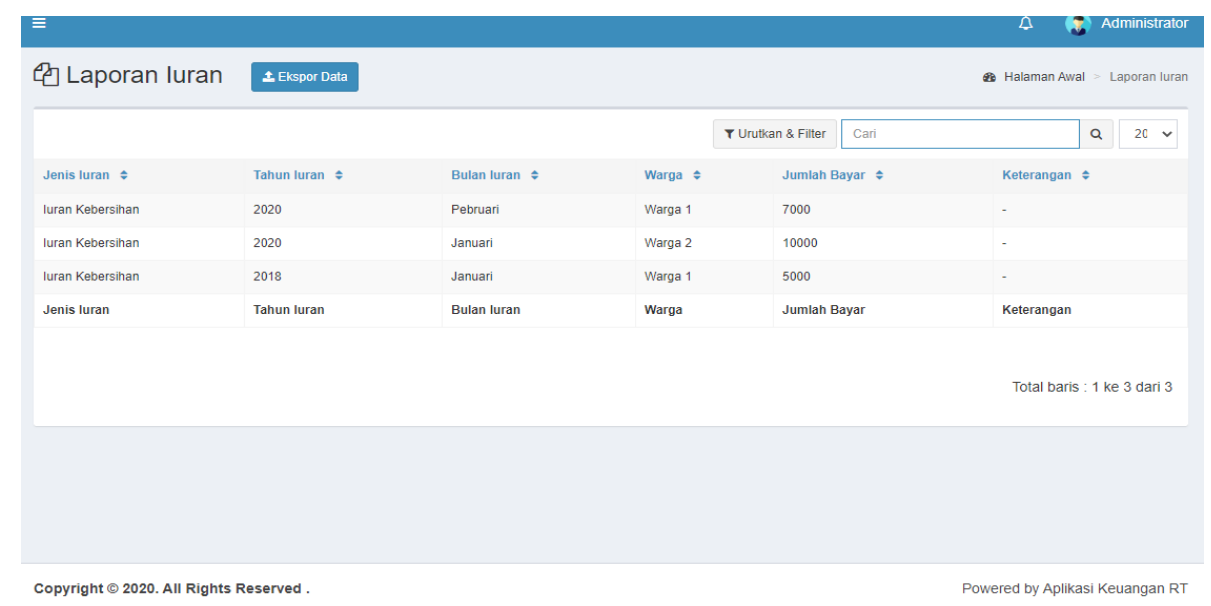

Gambar 8: Halaman Laporan Keuangan Masuk 
5. Implementasi User Interface Halaman Laporan Pengeluaran

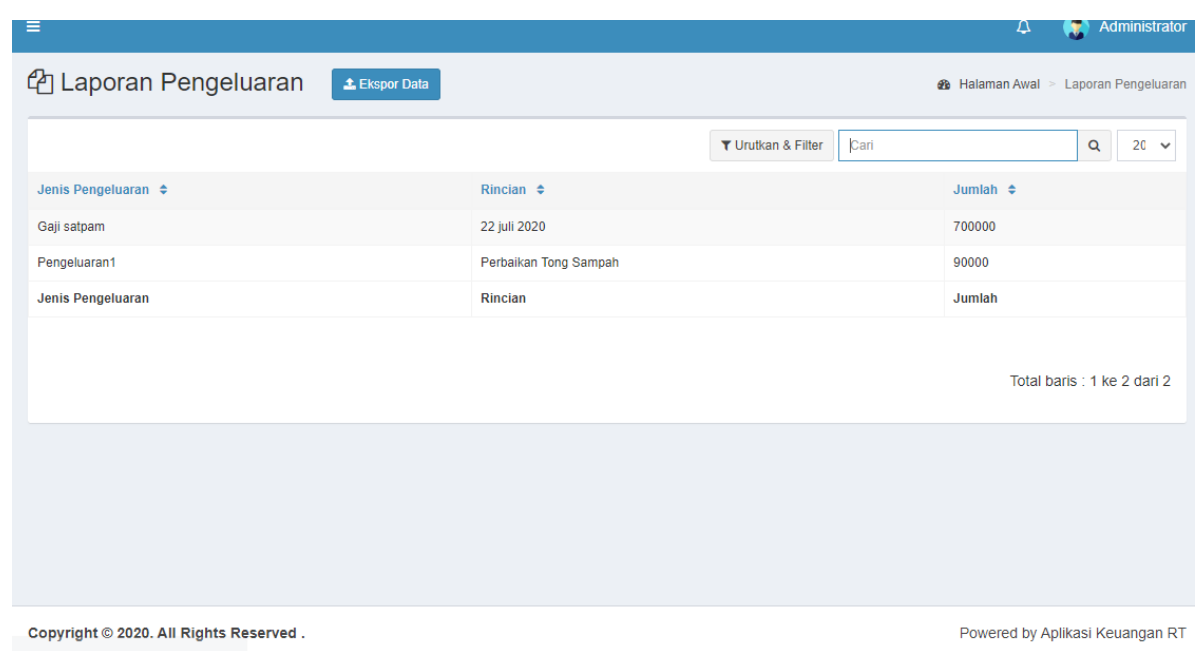

Gambar 9: Halaman Laporan Keuangan Keluar

Kemudian aktivitas kedua yang dilakukan pada tahapan ini adalah pengujian pada sistem informasi manajemen keuangan RT/RW. Dimana pengujian yang digunakan adalah pengujian black box testing. Berikut ini merupakan hasil pengujian sistem yang disajikan pada Tabel 2.

Tabel 2: Hasil Pengujian Sistem

\begin{tabular}{cllc}
\hline No & \multicolumn{1}{c}{ Komponen } & Hasil yang Diharapkan & Keterangan \\
\hline 1 & Login & Masuk ke aplikasi & Sesuai \\
\hline 2 & Halaman Utama & Berhasil masuk ke halaman utama & Sesuai \\
\hline 3 & Mengelola Pengguna & Berhasil mengelola data pengguna & Sesuai \\
\hline 4 & Mengelola Data Warga & Berhasil mengelola data warga & Sesuai \\
\hline 5 & Mengelola Iuran Warga & Berhasil mengelola iuran warga & Sesuai \\
\hline 6 & Mengelola Jenis Iuran & Berhasil mengelola jenis iuran & Sesuai \\
\hline 7 & Mengelola Bulan Iuran & Berhasil mengelola bulan iuran & Sesuai \\
\hline 8 & \multirow{2}{*}{ Melihat Periksa Iuran Warga } & $\begin{array}{l}\text { Berhasil melihat iuran warga yang sudah } \\
\text { bayar dan belum bayar }\end{array}$ & \multirow{2}{*}{ Sesuai } \\
\hline 9 & Mengelola Jenis Pengeluaran & Berhasil mengelola jenis pengeluaran & Sesuai \\
\hline 10 & Melihat Laporan Pemasukan & Berhasil melihat laporan pemasukan & Sesuai \\
\hline 11 & Melihat Laporan Pengeluaran & Berhasil melihat laporan pengeluaran & Sesuai \\
\hline
\end{tabular}

\section{KESIMPULAN}

Setelah dilakukan penelitian ini didapat hasil berupa sistem informasi manajemen keuangan RT/RW berbasis web yang dapat mengelola berbagai macam keuangan iuran warga, menampilkan laporan pemasukan dan pengeluaran iuran. Sistem informasi ini dirancang menggunakan metodologi Unified Approach dan menggunakan Unified Modeling Language sebagai dasar pemodelannya. Saran untuk pengambangan selanjutnya diharapkan ada yang menambahkan fitur pembayaran secara langsung dan menambahkan fitur notifikasi tunggakan pada sistem informasi majemen keuangan RT/RW serta mengembangkan aplikasi menggunakan platform android. 


\section{DAFTAR PUSTAKA}

[1] R. Setiawan, D. Kurniadi, and H. Bunyamin, "Perancangan Sistem Pengelolaan Penanggulangan Bencana Alam Garut Berbasis Sistem Informasi Geografis,” J. Algoritm., vol. 14, no. 2, pp. 343-349, 2015, doi: 10.33364/algoritma/v.14-2.343.

[2] J. Romansyah, A. Mulyani, and D. Kurniadi, "Rancang Bangun Sistem Informasi Penggalangan Dana Sosial Panti Asuhan Berbasis Web," J. Algoritm., vol. 16, no. 2, pp. 158-165, 2020, doi: 10.33364/algoritma/v.16-2.158.

[3] S. W. Anita, "Sistem Informasi RT/RW Sebagai Media Komunikasi Warga Berbasis Web," SMATIKA, vol. 4, no. 1, 2015.

[4] G. G. N. Huda, "Perancangan Sistem Informasi Pengelolaan Administrasi Keuangan Sekolah Menengah Atas Mengunakan Metode Pendekatan Unified Approach,” J. Algoritm., vol. 13, no. 1, pp. 226-231, 2016.

[5] N. Y. Rusmana, "Sistem Informasi Pengelolaan Keuangan Dana Bantuan Pada Kecamatan Arjosari," Speed-Sentra Penelit. Eng. dan Edukasi, vol. 7, no. 2, 2017.

[6] S. A. Nugraha and R. Setiawan, "Perancangan Sistem Informasi Pengolahan Administrasi Keuangan Sekolah Menengah Pertama Islam Terpadu Assalam Garut," J. Algoritm., vol. 13, no. 2, pp. 320-332, 2016.

[7] A. N. Hak, C. Slamet, and R. Kurniawati, "Implementasi Sistem Informasi Keuangan Siswa Berbasis SMS Gateway di SMK Muhammadiyah 2 Kadungora," J. Algoritm., vol. 11, no. 1, pp. 34-41, 2014.

[8] K. Kristina, "Pemodelan Sistem Informasi Pendataan Warga Dan Biaya Operasional Lingkungan Pada Komplek Perumahan Harmoni Park Berbasis Zachman Framework," J. Sains Komput. Dan Teknol. Inf., vol. 2, no. 1, pp. 55-62, 2019.

[9] A. Bahrmi, Object Oriented System Development. Singapore: Irwin/McGraw-Hill, 1999.

[10] A. Mulyani and R. R. M. Fadilah, "Rancang Bangun Sistem Informasi Ekstrakurikuler di Madrasah Aliyah Negeri 1 Garut Berbasis Web," J. Algoritm., vol. 14, no. 2, pp. 177-186, 2017.

[11] N. Anwary, A. D. Supriatna, and R. Kurniawati, "Rancang Bangun Aplikasi E-Commerce Di Outlet Persib Hardcore Menggunakan Metode Berorientasi Objek," J. Algoritm., vol. 11, no. 2, pp. 237-245, 2014.

[12] A. D. Supriatna and R. S. Yusuf, "Rancang Bangun Aplikasi Pemasaran Rumah Royal Rabbany Dengan Menggunakan Metode Unified Approach," J. Algoritm., vol. 14, no. 2, pp. 210-218, 2015, doi: 10.33364/algoritma/v.14-2.210. 